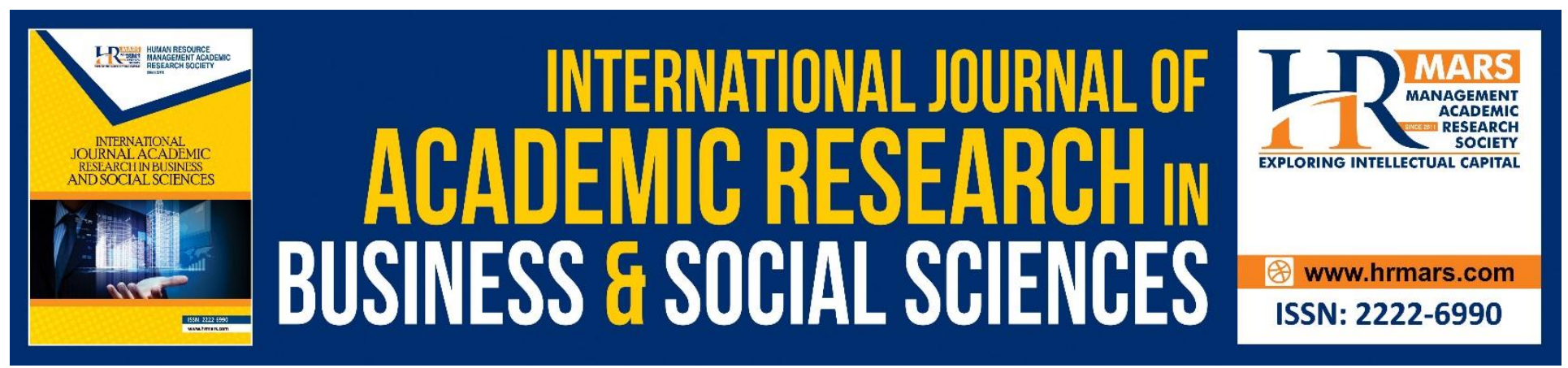

\title{
Credit Risk and Financial Performance of Banks Listed at the Nairobi Securities Exchange, Kenya
}

\section{Isabwa Harwood Kajirwa \& Nelima Wambaya Katherine}

To Link this Article: http://dx.doi.org/10.6007/IJARBSS/v9-i1/5407

DOI: $\quad 10.6007 /$ IJARBSS/v9-i1/5407

Received: 19 Dec 2018, Revised: 14 Jan 2019, Accepted: 23 Jan 2019

Published Online: 28 Jan 2019

In-Text Citation: (Kajirwa \& Katherine, 2019)

To Cite this Article: Kajirwa, I. H., \& Katherine, N. W. (2019). Credit Risk and Financial Performance of Banks Listed at the Nairobi Securities Exchange, Kenya. International Journal of Academic Research in Business and Social Sciences, 9(1), 400-413.

\section{Copyright: (C) 2019 The Author(s)}

Published by Human Resource Management Academic Research Society (www.hrmars.com)

This article is published under the Creative Commons Attribution (CC BY 4.0) license. Anyone may reproduce, distribute, translate and create derivative works of this article (for both commercial and non-commercial purposes), subject to full attribution to the original publication and authors. The full terms of this license may be seen at: http://creativecommons.org/licences/by/4.0/legalcode

$$
\text { Vol. 9, No. 1, 2019, Pg. } 400 \text { - } 413
$$

Full Terms \& Conditions of access and use can be found at http://hrmars.com/index.php/pages/detail/publication-ethics 


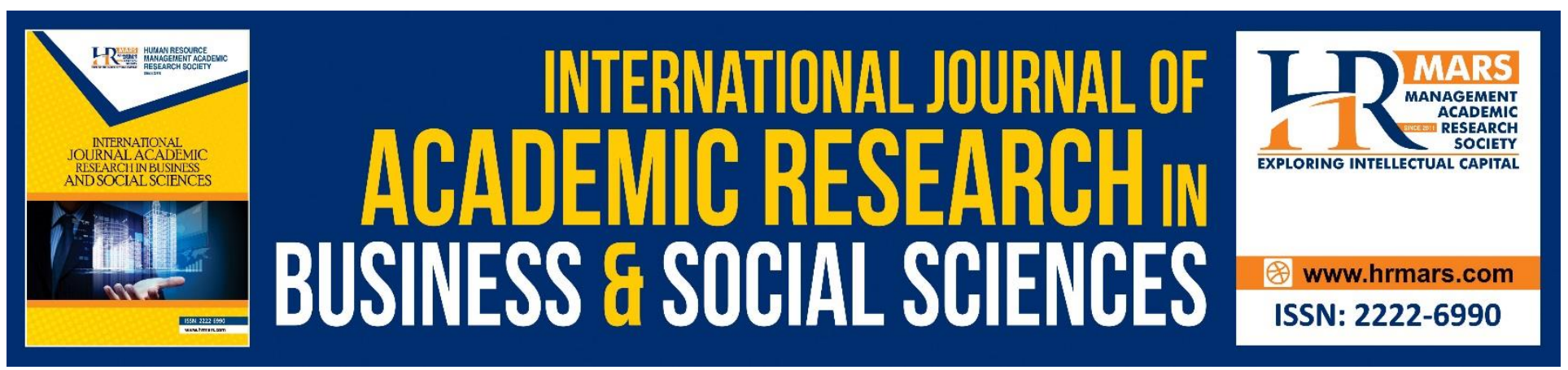

\title{
Credit Risk and Financial Performance of Banks Listed at the Nairobi Securities Exchange, Kenya
}

\author{
Isabwa Harwood Kajirwa1 Nelima Wambaya Katherine ${ }^{2}$ \\ ${ }^{1,2}$ Department of Business Management, \\ University of Eldoret, P.O. Box 1125-30100, Eldoret, Kenya. \\ Email:1,2harwoodisabwa@yahoo.com, nelimakatherine@yahoo.com, \\ 1,2Department of Business Management, University of Eldoret, Eldoret, Kenya.
}

\begin{abstract}
Introduction: Banks are often faced with risks that are mostly financial in nature. Effective management of risk is a prerequisite for sound financial performance of financial institutions. This study therefore analyses the effect of credit risk on financial performance of commercial banks listed at the Nairobi securities exchange. The specific objective was to determine the effect of credit risk on financial performance of commercial banks listed at the Nairobi securities exchange. Theories and models reviewed were the Capital Asset Pricing Model, Portfolio Theory, theory on risk and leverage and credit risk theory.
\end{abstract}

Methods: A positivism research philosophy was adopted. The study used a longitudinal research design. A target population of 11 Commercial banks listed at the Nairobi securities exchange was considered. The data was analyzed using Statistical package of social studies version 20.0. The data was analyzed using Karl Pearson correlation and regression inferential statistical techniques.

Results: The results showed that there was a significant strong correlation between credit risk and financial performance as proxied by $\operatorname{ROE}\left(r=-.601^{* *}, p=.003\right)$. The study found that credit risk significantly affects ROE $(\beta=-.601, p=007, \alpha<0.01)$. The model had an adjusted $r$ square value of 0.323 implying that $32.3 \%$ of the total variation of financial performance of commercial banks is explained by credit risk.

Conclusion: The study findings affirm that credit risk has a significant negative effect on banks financial performance. Upsurge in the banks ratio of nonperforming loans to total loans \& advances results into the reduction of the bank's financial performance.

Recommendations: The management of commercial banks should determine effective credit risk management strategies that could help in reduction of loan default rates by customers. Extensive loan underwriting should be conducted to avoid over or under charge on prospective customers. Progressive implementation of the Basel Accord should be prioritized as opined by the Basel Committee submission on Banking Supervision. Credit risk inherent to the entire portfolio as well as the risk in individual credits as transaction practice should be managed well. Standardized approach, 
INTERNATIONAL JOURNAL OF ACADEMIC RESEARCH IN BUSINESS AND SOCIAL SCIENCES

Vol. 9, No. 1, Jan, 2019, E-ISSN: $2222-6990$ (C) 2018 HRMARS

internal ratings based approach such as foundation and advanced approach should be considered by financial institutions when assessing credit risk.

Keywords: Credit Risk, Nonperforming Loans, Financial Performance, Return On Equity, Kenya

\section{Introduction}

Commercial banks extend credit to individuals and corporate entity's so as to raise funds for investment. Lending represents the heart of the commercial banks and loans are the dominant assets as they generate the largest share of operating income. Loans however expose the commercial banks to the greatest level of risk. Banks are feeling the heat of a new Central Bank of Kenya directive on the treatment of non-performing loans which has inflated their bad book and forced them to set aside additional cash as provision for defaults (Ngigi, 2014). Central bank of Kenya now requires lenders to classify as non performing all loan accounts of a borrower who defaults on the repayment of any one of their multiple loans for more than three months. This provision saw banks' bad loans for 2013 jump 30.9 per cent to Sh80.6 billion, the highest in over six years, even outpacing growth in new credit advanced by the lenders (Ngigi, 2014). According to Basel Committee on Banking Supervision (2000) credit risk is the possibility that the counterparty or a loan borrower will not settle its obligations according to the terms agreed upon.

Credit risk management is the process of identifying, measuring, monitoring and control of risk arising from default in repayment of loans (Coyle, 2000). Credit extended to borrowers may be at the risk of default such that whereas commercial banks extend credit on the understanding that borrowers will repay their loans, some borrowers usually default and as a result, commercial banks income decrease due to the need to provision for the loans. An increase in commercial banks credit risk gradually leads to liquidity and solvency problems. Credit risk may increase if the commercial banks lends to borrowers it does not have adequate knowledge about.

Prior studies found that commercial banks are experiencing a rampant decrease in their financial performance as a result of inadequate credit risk management arising from limited institutional capacity, poor lending practices, inappropriate credit policies, volatile interest rates, laxity in credit assessment, poor management, government interference, inappropriate laws, low capital and liquidity levels, direct lending, massive licensing of commercial banks, inadequate supervision by the central bank and poor loan underwriting (Kithinji, 2010). Worldwide credit risk is presumed to date to be the most dominant risk in the banking sector. Similar situation is also in the Republic of Serbia. The typical dominant risk of average commercial bank is credit risk. At the end of third quarter of $2015,86 \%$ of all capital requirements of the bank supervision department were related to the credit risk. During previous years, similar domination of credit risk in the Serbia and other countries was seen. In Serbia, there is high level of the non performing loans which is one of the major problems of the bank supervision department. Commercial banks are together with the National bank of Serbia intensively looking for the solution to mitigate the proportion of nonperforming loans.

The proportion of nonperforming loans to total loans is more than $20 \%$ as opined by (Cecchetti \& Kharroubi, 2012). There was a credit crunch in the United States of America which in turn escalated to a full blown global financial crisis in 2008-2009. Led Leman Brothers a major U.S bank with global presence was declared bankrupt in 2008 thus producing challenges in the global financial market. In the year 2009 to 2015, United States, 486 banks were declared bankrupt. Asset worth 74,777.8 billion 
dollars were lost (Federal Deposit Insurance Corporation, 2015). African perspective reveals that a significant number of African countries have also had their share of bank failures. The Muslim Bank, Berini Bank and the Lagos Bank were declared bankrupt in 1960.

In Zimbabwe, the African Report (2014) reported that, the countries Deposit Protection Corporation has closed down six failed banks namely Sagit finance house, Genesis and Royal, the Century discount house, Rapid discount house and Trust bank with a total cost to depositors of 52.3 million dollars and 11 more banks labeled as financially distressed (Psillaki, Tsolas, \& DMargaritis, 2010). In Ghana's banking sector, the following Banks' collapsed, Bank for Credit, the National Savings, Bank for housing and construction, Commerce International, Meridian BIAO bank, Tano Agya Rural Bank, Ghana Cooperative Bank, Tana Rural Bank, City Savings and Loans, Credit Bank and City Savings and Loans.

In Kenya's banking sector, Imperial Bank, Dubai and Chase Bank were declared bankrupt (Mulwa \& Kosgei, 2016). The effective management of credit risk is essential to the long term success of any banking institution. Therefore this study sought to assess the extent to which credit risk affects financial performance of commercial banks listed at the Nairobi Securities exchange.

\section{Statement of the Problem}

Central Bank of Kenya statutes laid down in the Kenyan laws governs the operations of the commercial banks. The Central Bank of Kenya has however remained hitherto the main regulator in all aspects of their operations. One of the reasons for the birth of the Basel accord was to tame credit risk. It provides a definite and broad framework to manage credit risk but contrary to its inception it has not fully helped banks to overcome fully the burden of credit risk.

Clients of Imperial Bank in Kenya have not fully been reimbursed their deposits since the Bank was declared bankrupt in 2015.

Failure by the banks to properly evaluate credit risk may lead to insolvency and bankruptcy. Aggregated stress testing of Lithuanian banks results in 2002 showed that banks consider credit risk to be the most important risk, constituting over $62 \%$ of possible losses (Ochola, 2010). Also, there is incongruence in the findings of prior studies in regards to the effect of credit risk on Banks financial performance. Studies by Kolapo et al. (2012); Musyoki and Kadubo (2011) found that credit has a negative effect on Banks financial performance. On the other hand, Kithinji (2010) found that credit risk had no effect on Banks financial performance. Afriyie and Akotey (2012) found that credit risk has a positive effect on Banks financial performance. The incongruence in the findings warrants a further study to unearth the optimal effect of credit risk on Banks financial performance. Kithinji (2010) did a study on the effect of credit risk on financial perfomance of Banks in Kenya and found that profitability of commercial banks is not affected by the magnitude of credit risk exposure. The study did not use return on equity as a proxy for Banks financial performance. Abor (2005) recommends the use of return on equity as an optimal measure of the efficiency of Banks as it illustrates to what extent banks use reinvested income to generate future profits (Foong, 2008). It would be profound if the researchers are able to find out the actual effect of credit risk on financial performance of commercial banks. The current study therefore, sought to fill this knowledge gap by investigating the effect of credit risk on financial performance of commercial banks listed at the Nairobi securities exchange. The remainder of this article paper is organized as follows. Section 2 
INTERNATIONAL JOURNAL OF ACADEMIC RESEARCH IN BUSINESS AND SOCIAL SCIENCES

Vol. 9, No. 1, Jan, 2019, E-ISSN: 2222-6990 (C) 2018 HRMARS

covers review of past studies and defines the main hypothesis. Section 3 covers materials and methods. Section 4 covers the results and discussion. Section 5 presents the conclusion and recommendations.

\section{Literature Review and Hypothesis Development Theoretical Framework}

This study is conducted against the backdrop of four main theories on risk: Sharpe (1964) Capital Asset Pricing Theory (CAPM), Markowitz's (1959) Portfolio Theory, Hamada's (1972) theory on risk and leverage and Merton (1974) credit risk theory. The CAPM suggests that price or expected return of an asset is related to its risk-free rate, the systematic risk and the expected risky market's riskpremium.

Hence,

$E(R j)=R f+\beta j[E(R m-R f)]$

Where,

$E\left(R_{j}\right)$ : the expected return on the asset $j=1, \ldots ., N$,

$\mathrm{Rf}$ : the risk-free rate of return measured as treasury bill/bond yield,

$\mathrm{Rm}$ : the expected return for the risky market portfolio,

$\beta_{\mathrm{j}}$ : the individual asset's systematic risk relative to the risky market's portfolio, and

$\mathrm{E}(\mathrm{Rm}-\mathrm{Rf})$ : the expected risk-premium of risky market portfolio.

Applied to a portfolio of bank loans, bank managers may be said to maintain a combination of loans with varying risk levels. The portfolio of bank loans would have to be such that the overall risk of the loans is diversified given the covariance of returns from each pair of loans is likely to be such that the correlation coefficient is closer to 0 rather than exactly equal to +1.00 as suggested by the Markowitz for diversifying individual asset's (loan) risk. Equation 1 denotes that, for risky loans, bank managers would charge a premium equal to the difference between the overall risk-premium applicable in the 'market' for all the loans in the market $\left(R_{t}-R_{m t}\right)$ in order for the banks to compensate themselves for the additional risk of a particular loan.

In essence, the CAPM infers that the required rate of return demanded by banks is equal to a riskfree rate (equivalent to the yield of a Treasury instrument with the same term as that of the loan) plus a premium as determined in the market for the total loan holding. Accordingly, a bank will price its loans according to the level of risk perceived whereby a perceived higher (lower) risk loan will attract a higher (lower) price for lending. Since individual loan risk can be eliminated through loan diversification as stated by Markowitz, the risk that a bank is concerned with in its loan-pricing decision is the market risk and the price of risk is:

Price of risk $=$ unit of risk $x$ risk-premium $=\beta \mathrm{j}[\mathrm{E}(\mathrm{Rm})-\mathrm{RF}]$

As a highly-levered firm, a bank has to incorporate in its loan pricing, other risk related costs for example, tax and bankruptcy cost.

Bankruptcy costs will arise if a bank indulges in excessive risk-taking lending or trading. Thus, risk increases if debt to equity ratio increases for a bank. Incorporating the leverage effect (Hamada op cit.) into Equation (2), beta of an individual bank, j, with loan capital can be expressed as:

ßjL = ßju $[1+\mathrm{D} / \mathrm{Ej}(1-\mathrm{tc})]$ 
Where, $\beta j L=$ beta of levered firm, $\beta j U$ = beta of unlevered firm, D/E = debt-equity ratio, tc = tax rate applicable to income streams of a bank. A banking firm's risk increases as leverage increases. Thus, capital structure is likely to affect credit risk. To summarize it up all, Merton (1974) espoused the credit risk theory which opines that default event is derived from a firm's asset evolution modeled by a diffusion process with constant parameters. Default can happen throughout all the life of a financial asset and not only in maturity (Longstaff \& Schwartz, 1995). There are three quantitative approaches in the analysis of credit risk: structural approach, incomplete information approach and reduced form appraisal (Crosbie et al., 2003).

Such models are normally defined as "structural model" and established on variables associated with a particular issuer. Cantor and Packer (1996) posit that credit risk theory is the main freely existing portfolio theory for credit risk assessment. The credit risk method gives room for a company to combine credit risk across its whole company, and gives a statement of value at risk as a result of credit resulting from upgrades, downgrades, and defaults. Credit risk model is helpful to all firms that are exposed to credit risk during their operations. The theory emphasizes that a firm ought to develop an approach to measure credit risk across a number of instruments such as, commitments and letters of credit, traditional loans; fixed income instruments; commercial contracts for example market driven instrument for instance swaps and receivables and trade credits (Padilla \& Pagano, 2000).

\section{Concept of Financial Performance}

Financial performance is used as a general measure of a firm's overall financial status over a given period of time (Abor, 2005). The financial performance is measured using accounting key performance indicators such as Return on Assets, Earnings before interest and tax, Economic value added (Crabtree \& DeBusk, 2008). The advantage of these measurements is their general availability, since every profit oriented organization produces these figures for their yearly financial statements (Chenhall et al., 2007). This study adopted the use of Return on equity as an indication of a firm's "overall financial health" (Bodie et al., 2011). It is a ratio that is used by analysts to evaluate the financial performance of a firm. Return on Equity shows the income generated for the shareholder's by the equity, which is the financing provided by the shareholders (Alexander \& Nobes, 2004). It provided evidence as to whether a firm was able to find viable investment opportunities (Berk \& DeMarzo, 2011), something that was of great importance for firms that wanted to stay competitive. Return on equity is determined by "earnings before interest and tax divided by equity", following the lead of Abor (2005). Efficiency of banks can be measured by using the Return on Equity which illustrates to what extent banks use reinvested income to generate future profits (Foong, 2008).

\section{Credit Risk and Financial Performance}

Credit risk is the exposure faced by banks when a borrower defaults in honoring debt obligations on due date or at maturity (Coyle, 2000). The synonym of credit risk is counterparty risk and it not adequately managed it is capable of putting the bank in distress. A framework for understanding the impact of credit risk management on the profitability of Commercial banks' is realized through credit risk management. It maximizes bank's risk adjusted rate of return by maintaining credit risk exposure within acceptable limit in order (Kargi, 2011). Felix and Claudine (2008) researched on the relationship between bank performance and credit risk management. They found that return on 
equity was inversely related to the ratio of non-performing loan to total loan \& advances of financial institutions thereby leading to a decline in a firm's financial performance.

Scholarly works of Jimenez and Saurina (2004) on bank specific credit risk determinants in Spain revealed that collateralised loans have a higher probability of default .They find that banks, whose probability of loan defaults is protected by collateral, have less incentives to undertake adequate screening and credit assessment at the time of loan approval. Type of loan is also a significant determinant of credit risk where loans given by saving banks are riskier and are prone to default. $A$ close bank to borrower relationship is also found to be significantly positively related to credit risk where this relationship increases the banks' willingness to take more credit risk by lending to riskier firms. Kargi (2011) researched on the impact of credit risk on the profitability of Nigerian banks.

Financial ratios as measures of bank performance and credit risk were collected from the annual reports and accounts of sampled banks from 2004-2008 and analyzed using correlation and regression techniques. The findings revealed that credit risk has a significant impact on the profitability of Nigerian banks. The researcher concluded that the levels of loans and advances, non performing loans and deposits are negatively related to banks' profitability as they expose Commercial banks to great risk of illiquidity and financial distress.

Ahmad \& Ariff (2007) examined the key determinants of credit risk of commercial banks on emerging economy banking systems compared with the developed economies. The study found that regulation is a prerequisite for banking institutions that offer multi services and products; management quality is critical in the cases of loan dominant banks in emerging economies. Upsurge in loan loss provision is also considered as a factor influencing credit risk. The study findings further revealed that credit risk in emerging economy banks is higher than that in developed economies.

Hosna et al. (2009) researched on Credit Risk Management and Profitability in Commercial Banks in Sweden. Panel data was extracted from the final accounts of banks sampled for the study for the period between 2000 to 2008 and capital adequacy and risk management reports (2007-2008). A sample size of four commercial banks in Sweden was studied. Regression model was used to do the empirical analysis. The study revealed that there is a positive relationship between credit risk and profitability on four commercial banks in Sweden during 2000 to 2008.

Kolapo et al. (2012) researched on the quantitative effect of credit risk on the performance of commercial banks in Nigeria. Five commercial banking firms were selected on a cross sectional basis for eleven years between 2000 and 2010. The ratio of Total loan \& Advances to Total deposit (LA/TD), the ratio of loan loss provision to classified loans (LLP/CL and the ratio of Non-performing loan to loan \& Advances (NPL/LA) were used as proxies of credit risk. Return on Equity was used to measure the financial performance of the commercial banks. The determinants of the profitability function were estimated using the Panel model analysis. The researchers found a negative relationship between credit risk and the profitability on 5 Nigerian commercial banks over 2000-2010.

Ruziqa (2013) investigated the joint effect of credit risk and liquidity risk on the profitability of large banks of Indonesia. This study focuses on Indonesian Conventional Bank with total asset above 10 trillion Rupiah within 2007 to 2011. The constructs of the financial performance of the Banks' were; return on equity, net interest margin and return on asset; credit risk are measured by non-performing loan ratio and liquidity risk are measured by liquidity ratio. The study found that credit risk has a 
INTERNATIONAL JOURNAL OF ACADEMIC RESEARCH IN BUSINESS AND SOCIAL SCIENCES

Vol. 9, No. 1, Jan, 2019, E-ISSN: 2222-6990 (C) 2018 HRMARS

negative effect on the profitability of commercial banks in Indonesia. The literature reviewed above led to the following hypothesis statement:

$H_{01}$ : Credit risk has no significant effect on $R O E$

\section{Materials \& Methods}

Research philosophy can simply be defined as a belief about the way in which data about a phenomenon should be gathered, analyzed and used (Cooper, Schindler, \& Sun, 2006). For this study, a positivism research philosophy was adopted. The choice for the positivism research philosophy is supported by the principle underlying this philosophy. According to the principles of positivism, the philosophy depends on quantifiable observations that lead themselves to statistical analysis (Kothari, 2004). It is noted that positivism is in accordance with the empiricist view that knowledge stems from human experience (Singh, 2006). This principle conforms to the nature of the study in that it deals with the quantifiable observations. With regard to the progression of this study, it was guided by the hypotheses in attempt to show the association between independent variable and dependent variable. All these attributes of the study apply for the positivism research philosophy hence its choice as the ideal research philosophy.

This study used a longitudinal research design because the current study used panel data. This research design is suitable for the study as it deals with the observations on the same subjects in different times. Panel data was employed because it helps to study the behavior of each bank over time and across space (Baltagi, 2005). Panel data allows for the use of existing data that heen recorded for any time period. The study period under consideration is between 2014 to 2018 . The study targeted eleven Commercial banks listed at the Nairobi securities Exchange. The study used Pearson product moment correlation analysis to assess the nature of relationship between the dependent variable (ROE) and the independent variable (credit risk). The ratio of nonperforming loan to total loan \& Advances (NPL/LA) was used as an indicator of credit risk. The correlation coefficient value $(r)$ ranging from 0.10 to 0.29 is considered weak, from 0.30 to 0.49 is considered medium and from 0.50 to 1.0 is considered strong (Wong \& Hiew, 2005). Regression analysis was used to identify the extent to which nonperforming loan to total loan \& Advances (NPL/LA) affects financial performance at $99 \%$ confidence level. The regression model was as follows: $R O E=B_{0}+B_{1} x_{1}+e$ Where; $X_{1}=$ Non performing loans to total loans $\&$ advances; $e=$ error term; $\beta_{0}, \beta_{k}=$ intercept; $\beta_{1}$, = coefficient of $x_{1}$.

\section{Empirical Results}

The results of Karl Pearson correlation revealed that credit risk has a strong negative association with Return on Equity $\left(r=-.601^{* *}, P=.003, \alpha<0.01\right)$. This implies that the proportion of nonperforming loans to total loans $\&$ advances has an inverse relationship with financial performance as proxied by Return on Equity as shown below in Table 4.1: 


\begin{tabular}{|c|c|c|c|}
\hline \multicolumn{4}{|c|}{ Correlations } \\
\hline & & $\begin{array}{l}\text { Nonperforming } \\
\text { loans to total } \\
\text { loans \& } \\
\text { advances }\end{array}$ & $\begin{array}{l}\text { Return on } \\
\text { Equity }\end{array}$ \\
\hline \multirow[t]{2}{*}{$\begin{array}{l}\text { Nonperforming loans to } \\
\text { total loans \& advances }\end{array}$} & $\begin{array}{l}\text { Pearson Correlation } \\
\text { Sig. (2-tailed) }\end{array}$ & 1 & \\
\hline & $\mathrm{N}$ & 11 & \\
\hline \multirow[t]{3}{*}{ Return on Equity } & Pearson Correlation & $-.601^{* *}$ & 1 \\
\hline & Sig. (2-tailed) & .003 & \\
\hline & $\mathrm{N}$ & 11 & 11 \\
\hline
\end{tabular}

**. Correlation is significant at the 0.01 level (2-tailed).

Source: (Survey data, 2019)

\section{Regression Analysis}

Simple linear regression model was used to predict financial performance in the study. The prediction was carried out basing on the effect of credit risk on financial performance of commercial banks listed at the Nairobi Securities Exchange. The findings indicated that the model coefficient of determination (adjusted R square) was 0.323 which indicated that $32.3 \%$ total variation of financial performance is explained by credit risk as shown in Table 4.2 .

Table 4.2: Regression Model Summary

$\begin{array}{ccccc}\text { Model } & \mathrm{R} & \mathrm{R} \text { Square } & \text { Adjusted R Square } & \text { Std. Error of the Estimate } \\ 1 & .601^{\mathrm{a}} & .361 & .323 & 8.31300\end{array}$
a. Predictors: (Constant), Non performing loans to total loans \& advances

Source: (Survey data, 2019)

\section{Analysis of Variance}

Analysis of Variance was employed to measure the differences in means between financial performance and credit risk as proxied by ratio of nonperforming loans to total loan advance and Return on Equity respectively. The F-ratio was 9.598 at 1 degree of freedom which is the variable factor. This represented the effect size of the regression model and was significant with a $p$-value of 0.007 as tabulated below. 
INTERNATIONAL JOURNAL OF ACADEMIC RESEARCH IN BUSINESS AND SOCIAL SCIENCES

Vol. 9, No. 1, Jan, 2019, E-ISSN: 2222-6990 @ 2018 HRMARS

Table 4.3 ANOVA

\begin{tabular}{ccccccc}
\hline Model & & Sum of & Df & Mean Square & $F$ & Sig. \\
& & Squares & & & & \\
1 & Regression & 663.268 & 1 & 663.268 & 9.598 & $.007^{\mathrm{a}}$ \\
& Residual & 1174.802 & 17 & 69.106 & & \\
\multicolumn{2}{c}{ Total } & 1838.070 & 18 & & & \\
\multicolumn{2}{l}{ a. Predictors: (Constant), Non performing loans to total loans } \\
\hline
\end{tabular}

Source: (Survey data, 2019)

The research findings concur with Kargi (2011), Felix and Claudine (2008), Ruziqa (2013), and Kolapo et al. (2012) that credit risk has a significant negative effect on the financial performance of commercial banks. This implies that commercial banks' profitability is inversely influenced by the levels of non-performing loans to total loan \& advances there by exposing them to great risk of illiquidity and distress. The study disagrees with the findings of Hosna et al. (2009); Afriyie and Akotey (2012) that credit risk has a significant positive effect on the financial performance of commercial banks. However, research findings show inconsistency with the hypothesis since credit risk recorded coefficient estimates of $\left(\beta_{1}=-.601, P=0.007, \alpha<0.01\right)$ as shown in Table 4.4 , hence we reject the null hypothesis $\left(\mathrm{H}_{0} 1\right)$ and conclude that credit risk significantly affects financial performance as measured by ROE.

Table 4.4: Regression Co efficient Analysis

\begin{tabular}{|c|c|c|c|c|c|c|}
\hline \multirow[t]{2}{*}{ Mode } & & \multicolumn{2}{|c|}{$\begin{array}{l}\text { Unstandardized } \\
\text { Coefficients }\end{array}$} & \multirow{2}{*}{$\begin{array}{c}\text { Standardized } \\
\text { Coefficients } \\
\text { Beta }\end{array}$} & \multirow[t]{2}{*}{$\mathrm{T}$} & \multirow[t]{2}{*}{ Sig. } \\
\hline & & B & Std. Error & & & \\
\hline \multirow[t]{2}{*}{1} & (Constant) & 34.265 & 2.309 & & 14.840 & .000 \\
\hline & $\begin{array}{l}\text { Nonperforming loans } \\
\text { to total loans\& }\end{array}$ & -.317 & .102 & -.601 & -3.098 & .007 \\
\hline
\end{tabular}

a. Dependent Variable: Return on equity

Source: (Survey data, 2019)

As aforementioned, the model was found to be statistically significant. Further, the regression model can be outlined as follows: Return on Equity $=34.265+-.601 \mathrm{X}_{1}+2.309$

\section{Conclusions and Recommendations}

The study findings affirm that credit risk has a significant negative effect on banks financial performance. Upsurge in the banks ratio of nonperforming loans to total loans \& advances results into the reduction of the bank's financial performance. There are other factors that affect financial performance of banks other than the ratio of nonperforming loans to total loans $\&$ advances. There was an increase in the rate of non performing loans in the banks considered in this study therefore the study recommended that the top management of banking institutions should determine effective credit risk management strategies that can help in mitigation of loan default rates by customers. Credit risk assessment approaches such as standardized approach and internal ratings based 
approach as suggested by Base II of the Basel Accord should be considered when assessing credit risk. Adoption of these approaches will help to seal loopholes in the whole lending process. Extensive loan underwriting should be conducted to avoid over or under charge on prospective customers. Progressive implementation of the Basel Accord should be prioritized as opined by the Basel Committee submission on Banking Supervision. These will ensure frameworks on credit risk analysis are fully adhered to when conducting credit risk management. Credit risk inherent to the entire portfolio as well as the risk in individual credits as transaction practice should be managed well. Attention should be paid to changes in economic or other circumstances that lead to deterioration in the credit standing of financial institution's counterparties.

The current study used the credit risk theory for credit risk assessment by Cantor and Packer (1996). The theory emphasizes that a firm ought to develop an approach to measure credit risk across a number of instruments such as, commitments and letters of credit, traditional loans; fixed income instruments; commercial contracts for example market driven instrument for instance swaps and receivables and trade credits (Padilla \& Pagano, 2000). One of the major theoretical implications of this study is that standardized approach, internal ratings based approach such as foundation and advanced approach according to Basel II of the Basel Accord should be considered when assessing credit risk. Future studies on credit risk and financial performance of commercial banks should consider the ratio of nonperforming loans to total loan advances as a proxy of credit risk. Return on equity should also be considered as an efficient measure of bank financial performance when evaluating the relationship between credit risk and the financial performance of commercial banks.

\section{References}

Abor, J. (2005). The effect of capital structure on profitability: an empirical analysis of listed firms in Ghana. The journal of risk finance, 6(5), 438-445.

Afriyie, H. O., \& Akotey, J. O. (2012). Credit risk management and profitability of selected rural banks in Ghana. Ghana: Catholic University College of Ghana.

Ahmed, A. S., Takeda, C., \& Thomas, S. (1999). Bank loan loss provisions: a reexamination of capital management, earnings management and signaling effects.Journal of accounting and economics, 28(1), 1-25.

Alexander, D., \& Nobes, C. (2004). Financial accounting: an international introduction. Pearson Education.

Baltagi, B. H. (2005). Econometric Analysis of Data Panel. England: John Wiley \& Sons Ltd.

Berk, J., \& DeMarzo, P.M. (2011).Corporate Finance. (2nd Ed.). Harlow: Pearson Education Limited.

Bodie, Z., Kane, A., \& Marcus, A. J. (2011). Investment and portfolio management. McGraw-Hill Irwin. 
INTERNATIONAL JOURNAL OF ACADEMIC RESEARCH IN BUSINESS AND SOCIAL SCIENCES

Vol. 9, No. 1, Jan, 2019, E-ISSN: 2222-6990 (C) 2018 HRMARS

Brealey, R. A., Myers, S. C., \& Allen, F. (2011). Principles of corporate finance 10 th edition McGrawHill.

Cantor, R., \& Packer, F. (1996). Determinants and impact of sovereign credit ratings. Economic Policy Review, 2, 37-53.

Cecchetti S. G., \& Kharroubi, E. (2012). Reassessing the impact of finance on growth. Bank for international settlements, BIS working papers, 381.

Cooper, D. R., Schindler, P. S., \& Sun, J. (2006). Business research methods (Vol. 9). New York: McGraw-Hill Irwin.

Coyle, B. (2000). Framework for Credit Risk Management; Chartered Institute of Bankers, United Kingdom.

Crosbie, P., \& Bohn, J. (2003). Assessing how bankruptcy prediction models are evaluated. Journal of Business and Economic Research, 3(1), 87-92.

Chenhall, R. H., \& Langfield-Smith, K. (2007). Multiple perspectives of performance measures. European Management Journal, 25(4), 266-282.

Crabtree, A. D., \& DeBusk, G. K. (2008). The effects of adopting the balanced scorecard on shareholder returns. Advances in Accounting, 24(1), 8-15.

Felix, A. T., \& Claudine, T. N. (2008). Bank performance and credit risk management. Unpublished Masters Dissertation in Finance, University of Skovde.

Foong, K. (2008). Return-on-Equity ratio can show how efficient banks are. Malaysian Institute of Economic Research.

Hamada, R. S. (1972). The effect of the firm's capital structure on the systematic risk of common stocks. The journal of finance, $27(2), 435-452$.

Hosna, A., Manzura, B., \& Juanjuan, S. (2009). Credit risk management and profitability in commercial banks in Sweden. rapport nr.: Master Degree Project 2009: 36.

Jiménez, G., \& Saurina, J. (2004). Collateral, type of lender and relationship banking as determinants of credit risk. Journal of banking \& Finance, 28(9), 2191-2212.

Kargi, H. S. (2011). Credit risk and the performance of Nigerian Banks. Ahmadu Bello University, Zaria. 
INTERNATIONAL JOURNAL OF ACADEMIC RESEARCH IN BUSINESS AND SOCIAL SCIENCES

Vol. 9, No. 1, Jan, 2019, E-ISSN: 2222-6990 (C) 2018 HRMARS

Kieso, D. E., Weygandt, J. J., \& Warfield, T. D. (2010). Intermediate accounting: IFRS edition (Vol. 2). John Wiley \& Sons.

Kithinji, A. M. (2010). Credit risk management and profitability of commercial banks in Kenya. Unpublished Masters Thesis, University of Nairobi.

Kolapo, T. F., Ayeni, R. K., \& Oke, M. O. (2012). Credit risk and commercial banks' performance in Nigeria: A panel model approach. Australian Journal of Business and Management Research, 2(2), 3138.

Kothari, C. R. (2004). Research methodology: Methods and techniques. New Age International.

Longstaff, F. A., \& Schwartz, E. S. (1995). A simple approach to valuing risky fixed and floating rate debt. The Journal of Finance, 50(3), 789-819.

Markowitz, H. M. (1991). Foundations of portfolio theory. The journal of finance, 46(2), 469-477.

Merton, R. C. (1974). On the pricing of corporate debt: The risk structure of interest rates. The Journal of finance, 29(2), 449-470.

Mulwa, J. M., \& Kosgei, D. (2016). Commercial Bank Diversification and Financial Performance: The Moderating Role of Risk. Journal of Finance and Investment Analysis, 5(2), 31-52.

Musyoki, D., \& Kadubo, A. S. (2012). The impact of credit risk management on the financial performance of banks in Kenya for the period. International Journal of Business and Public Management, 2(2), 72-80.

Ngigi, G. (2014). M-Shwari Lifts CBA above Equity in Loan Accounts. Business Daily Africa, 9.

Ochola, J. O. (2010). Effect of credit risk management practices on financial performance of commercial banks in Kenya. Unpublished Masters Thesis, University of Nairobi.

Padilla, A. J., \& Pagano, M. (2000). Sharing default information as a borrower discipline device. European Economic Review, 44(10), 1951-1980.

Richardson, D. C. (2002). PEARLS Monitoring system World Council information center. Maddison, WI, WOCCU Toolkit series, (4).

Ruziqa, A. (2013). The impact of credit and liquidity risk on bank financial performance: the case of Indonesian Conventional Bank with total asset above 10 trillion Rupiah. International Journal of Economic Policy in Emerging Economies, 6(2), 93-106. 
INTERNATIONAL JOURNAL OF ACADEMIC RESEARCH IN BUSINESS AND SOCIAL SCIENCES

Vol. 9, No. 1, Jan, 2019, E-ISSN: 2222-6990 @ 2018 HRMARS

Singh, Y. K. (2006). Fundamental of research methodology and statistics. New Age International.

Sharpe, W. F. (1964). Capital asset prices: A theory of market equilibrium under conditions of risk. The journal of finance, 19(3), 425-442. 